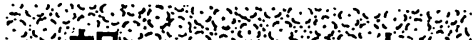 \\ 㘧 \\ 6. \\ 食品中のアセスルファム $\mathrm{K}$ ，サッカリン及び \\ アスパルテームの含有量
}

(平成 4 年 10 月 21 日受理)

$\begin{array}{lll}\text { 守安貴子* } & \text { 斉藤 和夫* } & \text { 中里光男* } \\ \text { 石川ふさ子* } & \text { 藤 沼 賢司* } & \text { 二島太一郎* }\end{array}$

\section{Amounts of Acesulfame K, Saccharin and Aspartame Used in Foods}

Takako Moriy asu, Kazuo Saito, Mitsuo Nakazato, Fusako Ishikawa, Kenji Fujinuma and Taichiro Nishima

(The Tokyo Metropolitan Research Laboratory of Public Health: 3-24-1, Hyakunin-cho, Shinjuku-ku, Tokyo 169, Japan)

The contents of three sweeteners [acesulfame $\mathrm{K}(\mathrm{AK})$, saccharin (SA) and aspartame (APM)] in 203 samples of foods, either imported, purchased on a trip abroad, or made in Japan, were examined. In soft drinks, we detected both SA and APM in three samples manufactured in the U.S.A., AK and APM in three samples manufactured in the U. K. and only APM in three samples manufactured in Japan. In powdered soft drinks, we detected AK and APM, and SA and APM in British and Japanese products, respectively. In solid foods, we detected SA in three pickles and a confectionery (all Japanese-made).

Confirmation of AK was carried out as follows: samples were dialyzed against $0.1 \mathrm{~N}$ hydrochloric acid, and $\mathrm{AK}$ was extracted with ethyl acetate from the dialyzate. It was methylated with ethereal diazomethane, and analyzed by gas chromatography-mass spectrometry.

(Received October 21, 1992)

Key words： アセスルファム $\mathrm{K}$ acesulfame $\mathrm{K}$ ；サッカリン saccharin；アスパルテーム aspartame; 高速液体クロマトブラフィー high performance liquid chromatography；ガスクロマト グラフィー質量分析 gas chromatography-mass spectrometry

緒言

前報”において著者らは合成甘味料であるアセスルフ アム $\mathrm{K}(\mathrm{AK}), \quad$ サカリン $(\mathrm{SA})$ 及びアスパルテーム (APM) の同時分析法を作成した. 今回はこの分析法を用 いて, 輸入, 国産及び海外渡航時に購入した食品につい てこれら 3 種の甘味料の使用状況を調查した。 また, $\mathrm{SA}^{2)}$ 及び $\mathrm{APM}^{3)}$ については確認法が既に確立されてい るが, AK についてはこれまで報告されている AK の分

\footnotetext{
* 東京都立衛生研究所：干169 東京都新宿区百人町 3-24-1
}

析方法が逆相系による高速液体クロマトグラフィーを用 いたものがほとんど4 10)であり, 確認方法としては不十 分であった。 そこでガスクロマトグラフィー.マススペ クトロメトリー $(\mathrm{GC} / \mathrm{MS})$ による確認法について検討し たところ，良好な結果が得られたので併せて報告する。

\section{実験方法}

1. 試

1) $0.1 \mathrm{~N}$ 塩酸： $20 \%$ 塩酸（特級, 和光純薬工業(株)

製） $8.4 \mathrm{ml}$ に水を加えて $500 \mathrm{ml}$ とした.

2) ジアゾメタンーエーテル溶液 ${ }^{21,11)}: N$-メチル $N$-二 
トロソウレア (試験研究用, 岩井化学薬品(株)製) 約 20 $\mathrm{mg}$ を共栓試験管にとりエーテルで $50 \mathrm{ml}$ とした後, 水 浴中で冷却しながら $30 \%$ 水酸化ナトリウム溶液 $0.5 〜 1$ $\mathrm{ml}$ を静かに滴下させ，約 1 時間放置した。 得られた黄 色のジアゾメタンーエーテル溶液は別の容器に移し, 水 酸化ナトリウム約 $5 \mathrm{~g}$ で脱水した。なお，以上の操作は ドラフト内で行った.

AK, SA 及び APM 混合標準液, 透析用溶液, 透析膜, 前処理用カートリッジカラム，イオンペアー試薬及びメ タノールは前報1に準じた。

その他の試薬は市販特級品を用いた。

\section{2. 装置}

1) 高速液体クロマトグラフ：前報”に準じた。

2) ガスクロマトグラフーマススペクトロメーター: ガスクロマトグラフとしてバリアン社製 GC-3400 型に 質量分析計としてフィニガンマット社製 INCOS-50 型 を装着したあの.

3. HPLC 条件

前報1に従った。

4. 試料

昭和 63 年 4 月から平成 4 年 3 月までに都内で市販さ れていた輸入，国産の食品及び海外渡航時に購入した食 品, 合計 203 検体を分析に供した。 なお，その内訳は， 清凉飲料水 131 検体 (国産品 21 検体, 輸入品 107 検体 及び海外渡航時購入品 3 検体), 粉末清涼飲料 6 検体 （国産品 1 検体，輸入品 4 検体及び海外渡航時購入品 1 検体), 菓子類 13 検体（国産品），果物・野菜加工品 42 検体（国産品 22 検体，輸入品 20 検体）， その他の食品 11 検体（国産品 9 検体, 輸入品 2 検体）である.

\section{5. 試験溶液の調製及び定量}

前報 ${ }^{1} に$ 準じた。

\section{SA の確認}

衛生試験法 ${ }^{2}$ に準じ，ガスクロマトグラフィー $(\mathrm{GC})$ に より確認した.

\section{APM の確認}

井部らの方法 ${ }^{3)}$ に準じ，薄層クロマトグラフィー (TLC)により確認した.

\section{AK の確認}

1) 透析及び抽出繰作

透析用溶液に $0.1 \mathrm{~N}$ 塩酸を用い, 前報 ${ }^{1)}$ 同様に操作 し透析を行った。透析終了後透析外液 $100 \mathrm{ml}$ を分取し, 塩化ナトリウム $40 \mathrm{~g}$ を加え, 酢酸エチル $50 \mathrm{ml}$ で 3 回 抽出を行った. 抽出液は合わせて無水硫酸ナトリウムで 脱水した後, 溶媒を減圧留去し残留物を得た。

なお，糖分の少ない清涼飲料水などにおいては，その まま酢酸エチルを加え，上記と同様に抽出した際に液層 が良く分離するあのについては，透析操作は省略した。

2) メチル化操作 .

1)で得られた残留物にジアゾメタンーエーテル溶液の
Table 1. Classification of Samples by Kinds of Foods

\begin{tabular}{lcc}
\hline \multicolumn{1}{c}{ Sample } & $\begin{array}{c}\text { No. of } \\
\text { domestic } \\
\text { products }\end{array}$ & $\begin{array}{c}\text { No. of } \\
\text { imported } \\
\text { products }\end{array}$ \\
\hline Carbonated drink & 7 & 56 \\
Fruits juice drink & 5 & $53(3)$ \\
Powdered soft drink & 1 & $5(1)$ \\
Other soft drinks & 9 & 1 \\
Confectionery & 13 & 0 \\
Fruit preserves & 10 & 17 \\
Vegetable preserves & 12 & 3 \\
Other foods & 9 & 2 \\
\hline Total & 66 & 137 \\
\hline
\end{tabular}

( ): Numbers of foods bought on a trip abroad

Table 2. Classification of Samples by Producing Countries

\begin{tabular}{lc}
\hline \multicolumn{1}{c}{ Country } & No. of samples \\
\hline U.S.A. & 70 \\
France & 11 \\
U.K. & 6 \\
Canada & 5 \\
South Africa & 5 \\
Hong Kong & 5 \\
Australia & 4 \\
Philippines & 4 \\
Korea & 4 \\
Singapore & 3 \\
Thailand & 3 \\
China & 2 \\
Germany & 2 \\
Switzerland & 2 \\
Japan & 66 \\
Others (eleven countries) & 11 \\
\hline Total & 203 \\
\hline
\end{tabular}

黄色が十分持続するまで加え, 30 分間放置した。この後 エーテルを減圧留去し，残留物にアセトン $2 \mathrm{ml}$ を加え て溶解したものを $\mathrm{GC} / \mathrm{MS}$ 用試験溶液とした。

3) $\mathrm{GC} / \mathrm{MS}$ の測定条件

$\mathrm{GC}$ 条件

カラム: DB-5, 長さ $30 \mathrm{~m}$, 内径 $0.25 \mathrm{~mm}$, 膜厚 0.25 $\mu \mathrm{m}$ の fused シリカキャピラリーカラム（J \& W Scientific 社製); カラム温度： $100^{\circ}$ (1 分) $\rightarrow 200^{\circ}$ (2 分) $5^{\circ} / \min$ の昇温分析；注入口温度 $250^{\circ}$

MS 条件

測定モード：EI；トランスファーライン温度： $250^{\circ}$ ；

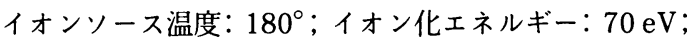


エミッションカレント：200 $\mu \mathrm{A}$

\section{結果及ひ考察}

\section{1. 調 查品目}

今回の調査に当たっては, AK, SA 及び APM の使用 される可能性が高く，我が国における輸入加工食品の中 で輸入量の多い ${ }^{111}$ 清涼飲料水 (137 検体)，果物加工品 （27 検体）を中心に総計 203 検体（国産品 66 検体，輸 入品 133 検体及び海外渡航時購入品 4 検体）について 検查を行った (Table 1)。 また，これらの食品の原産国を Table 2 に示したが，輸入品については我が国において

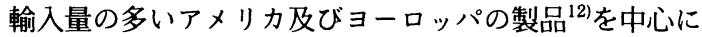
調査を行った。

\section{2. 使用実態調查}

AK, SA 及び APM の検査結果を Table 3 に示した.

\section{1) 炭酸飲料}

炭酸飲料のコーラ類では国産品から APM のみが 220 及び $490 \mu \mathrm{g} / \mathrm{g}$ 検出された. 輸入品からは SA が 200 $220 \mu \mathrm{g} / \mathrm{g}$ 及び $\mathrm{APM}$ が $75,72 \mu \mathrm{g} / \mathrm{g}$ 検出され，これら はいずれあ併用して使用されていたものであった。 ま た，サイダー類は国産品から APM のみが 120,200 $\mu \mathrm{g} /$ $\mathrm{g}$ 検出されたが，輸入品からは SA が $120 \mu \mathrm{g} / \mathrm{g}$, APM が $63 \mu \mathrm{g} / \mathrm{g}$ 検出され，これも併用して使用されていたも のであった.

炭酸飲料で，コーラ類及びサイダー類は国産品では APM が単独で使用されていたのに対して，輸入品はい ずれあ APM と SA が併用して使用されていた。なお， 今回 SA 及び APM が同時に検出された輸入品の原産国 はいずれあアメリカであった。

Table 3. Contents of Sweeteners Used in Foods

\begin{tabular}{|c|c|c|c|c|c|c|}
\hline \multirow{2}{*}{ Sample } & \multirow{2}{*}{$\begin{array}{l}\text { No. of } \\
\text { Samples }\end{array}$} & \multirow{2}{*}{$\begin{array}{c}\text { No. of } \\
\text { positive } \\
\text { samples }\end{array}$} & \multicolumn{3}{|c|}{ Content of sweeteners $(\mu \mathrm{g} / \mathrm{g})$} & \multirow{2}{*}{ Country } \\
\hline & & & AK & $\mathrm{SA}$ & APM & \\
\hline \multicolumn{7}{|l|}{ Carbonated drink } \\
\hline \multirow[t]{4}{*}{ Cola drinks } & 18 & 4 & - & - & 490 & Japan \\
\hline & & & - & - & 220 & Japan \\
\hline & & & - & 200 & 75 & U.S.A. \\
\hline & & & - & 220 & 72 & U.S.A. \\
\hline \multirow[t]{3}{*}{ Transparent carbonated drinks } & 9 & 3 & - & - & 200 & Japan \\
\hline & & & - & - & 120 & Japan \\
\hline & & & - & 120 & 63 & U.S.A. \\
\hline Carbonated drinks with fruit juice & 27 & & - & & & \\
\hline Others & 9 & - & & & & \\
\hline \multicolumn{7}{|l|}{ Fruit juice } \\
\hline Fruit juice drink (more than $50 \%$ ) & 13 & - & & & & \\
\hline \multirow{3}{*}{ Fruit juice drink (less than 50\%) } & 45 & 3 & 180 & - & 170 & U.K.* \\
\hline & & & 200 & - & 180 & U.K.* \\
\hline & & & 190 & - & 170 & U.K.* \\
\hline Fruit flavored and colored drink (0\%) & 4 & - & & & & \\
\hline \multicolumn{7}{|l|}{ Powdered soft drink } \\
\hline Instant coffee & 3 & - & & & & \\
\hline Instant tea & 1 & - & & & & \\
\hline Instant cocoa & 1 & 1 & 2,000 & - & 1,400 & U.K.* \\
\hline Fruit flavor & 1 & 1 & - & 740 & 820 & Japan \\
\hline Other drinks & 6 & - & & & & \\
\hline \multicolumn{7}{|l|}{ Solid food } \\
\hline Canned fruit or vegetable & 19 & - & & & & \\
\hline Fruit jam & 10 & - & & & & \\
\hline \multirow[t]{3}{*}{ Pickles } & 13 & 3 & - & 370 & - & Japan \\
\hline & & & - & 760 & - & Japan \\
\hline & & & - & 810 & - & Japan \\
\hline Confectionery & 13 & 1 & - & 370 & - & Japan \\
\hline Others & 11 & - & & & & \\
\hline Total & 203 & 16 & & & & \\
\hline
\end{tabular}

* Foods bought on a trip abroad 


\section{2) 果汁飲料}

果汁含有量が $50 \%$ 以上のものからは，これら 3 種の 甘味料は検出されなかった. $50 \%$ 未満のむのは 45 検体 中 3 検体から $\mathrm{AK}$ が $180 \sim 200 \mu \mathrm{g} / \mathrm{g}$, APM が 170 $180 \mu \mathrm{g} / \mathrm{g}$ 検出され，これらはいずれも併用して使用さ れていたあのであった。 またこの AK と APM が併用し て使用された果汁飲料の原産国はいずれもイギリスであ った.

\section{3）粉末清涼飲料}

粉末清凉飲料 12 検体中，インスタントココア及び粉 末オレンジジュースの 2 検体から甘味料が検出された。 すなわちインスタントココアからは AK が $2,000 \mu \mathrm{g} / \mathrm{g}$, $\mathrm{APM}$ が $1,400 \mu \mathrm{g} / \mathrm{g}$ 検出され, 粉末オレンジジュース からは, SA が $740 \mu \mathrm{g} / \mathrm{g}, \quad$ APM が $820 \mu \mathrm{g} / \mathrm{g}$ 検出され た。なお、インスタントココアの原産国はイギリスであ り，粉末オレンジジュースは国産品であった。

\section{4) 固形食品}

固形食品については果物及び野菜缶詰, ジャム, 漬物, 菓子類など， 66 検体について検査したところ，たくあ ん，福神漬などの漬物類 3 検体から SA が $370 〜 810$ $\mu \mathrm{g} / \mathrm{g}$ ，せんべいから $\mathrm{SA}$ が $370 \mu \mathrm{g} / \mathrm{g}$ 検出された。これ らはいずれも国産品であった。

以上の結果より, 清涼飲料水については, 輸入品では $\mathrm{SA}$ と APM，外国で購入したものでは AK と APM の ように APM と他の甘味料が併用して使用される傾向が

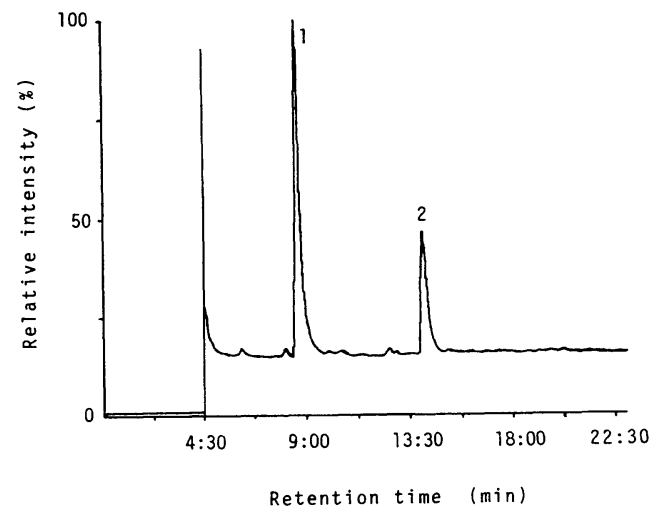

Fig. 1. Mass chromatogram of methylated derivatives of Acesulfame $\mathrm{K}(\mathrm{AK})$

1: $N$-methyl-AK; 2: $O$-methyl-AK<smiles>CC1=CC(=O)N(C)[R6](=O)O1</smiles>

$\mathrm{N}$-methyl-AK<smiles>COC1=N[R5](=O)OC(C)=C1</smiles>

0-methyl-AK
Fig. 2. Structures of methylated derivatives of $\mathrm{AK}$
認められた。これに対して国産品では APM が単独で使 用されている傾向が認められた。一般に，合成甘味料は その甘味度の相乗効果を期待したり，甘味の発現の早さ の違いを利用して甘味の幅を広げる，あるいは苦みや後 味を隠ぺいする目的で併用して使用することが多い13). しかし, 我が国では近年, 化学合成品以外の食品添加物 が好まれる傾向にあり，また，甘味の質で SA に比べて APM がすぐれているなどの点で，清涼飲料水には APM を単独で使用する傾向にあるのではないかと考え られる。

国産品の清凉飲料水は APM が単独で使用されていた のに対して，固形食品の漬物及び菓子類はいずれも SA が単独で使用されていた。この理由としては APM が加 熱や pH 6 以上で不安定であり, 微生物によっても分解 されやすいのに対して，SA はこれらの条件下でも安定 なため使用されたものと考えられる。 なお，今回は天然 甘味料については検査を行わなかったが, 国産品の漬物 類の多くは，添加物表示によると近年ではほとんど天然 甘味料であるステビアや甘草抽出物などが使用される傾 向にあるため ${ }^{14)}$ ，今回の調査では，SA の検出頻度が少 なかったものと考えられる.

今回 3 種の甘味料が検出された食品の 16 検体中 12 検体は清涼飲料水であった。 また，これらは「ダイェッ 卜」と称するものや「低カロリー」「美容」の文字を表し た医薬品のドリンク剤と類似の製品がほとんどであっ た。近年の瘦身指向により，消費者が手軽に利用できる 清凉飲料水にこれらの甘味料が多く使われているものと

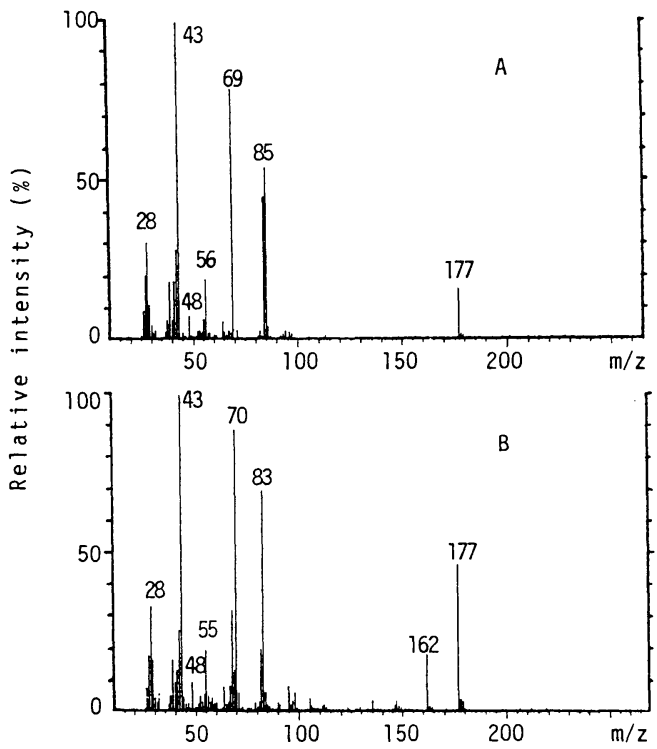

Fig. 3. Mass spectra of methylated derivatives of $\mathrm{AK}$

A: $N$-methyl-AK; B: $O$-methyl-AK 


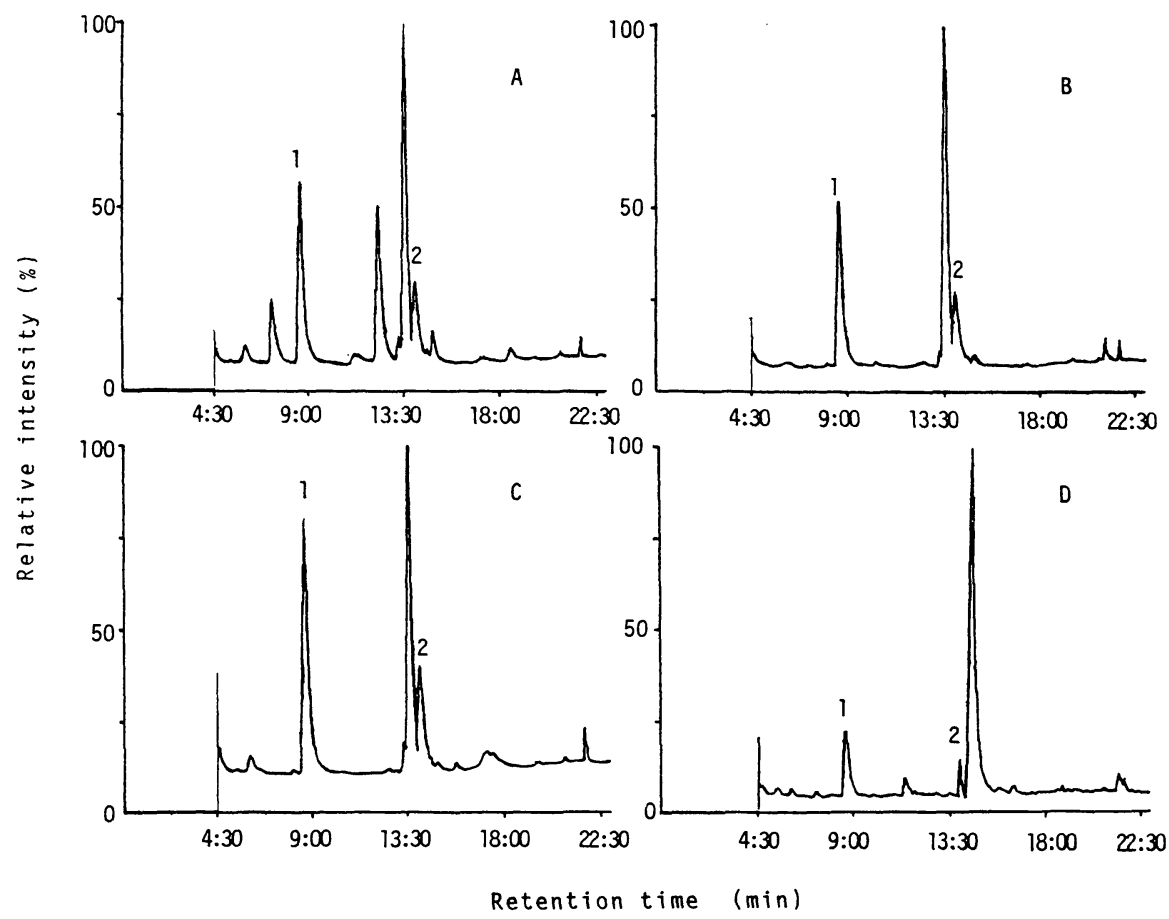

Fig. 4. Mass chromatograms of methylated derivatives of $A K$ extracted from samples

$\mathrm{A}$ : apple juice; $\mathrm{B}$ : orange juice; $\mathrm{C}$ : tropical juice; $\mathrm{D}$ : instant cocoa; 1: $N$-methyl-AK; 2 : $O$-methyl-AK

思われる，また，今回検出されたこれらの 3 種の甘味料 はいずれあ当該生産国では使用の認められているもので あった。特に AK は我が国では使用が認められていない が，イギリスをはじめ約 42 か国で使用が認められてお り，今回検出された製品はいずれあイギリス産のあので あった。なお， AK が検出された製品は，海外に渡航し た際に購入したものである.イギリスでは清涼飲料水を はじめ固形食品, 卓上甘味料などにその使用が認められ ている.

\section{AK の GC/MS による確認}

今回イギリスで購入した清涼飲料水及び粉末清涼飲料 から $\mathrm{AK}$ が検出されたが，我が国ではまだ $\mathrm{AK}$ を検出し た報告例はない，これまで報告されている $\mathrm{AK}$ の分析法 のほとんよ゙は HPLCによるものであり ${ }^{4 / 10)}$ ，数種の力 ラムや移動相の变更のみで， AK の確認をする事は確実 な確認方法ではないと考えた。 そこで, 全く分析モード を変えて GC を用いることとし，また確認をより確かに するため，質量分析を装着した $\mathrm{GC} / \mathrm{MS}$ による確認を試 みた，検討に当たっては， $\mathrm{AK}$ は気化しにくいためメチ ル化等により誘導体化する必要があるが， AK の構造が $\mathrm{SA}$ と類似していることから，SAの GC による分析法 ${ }^{2}$ を適用することとした。すなおち, 試料を透析後酷酸工 チルにより抽出し, 無水硫酸ナトリウムにより脱水, 溶
媒留去後, ジアゾメタンーエーテル溶液によるメチル化 を検討した，その結果 $\mathrm{AK}$ の酢酸エチルへの抽出率は 99\% と良く，また，簡便にメチル化体が得られたので， 本法によって得られたメチル化体をアセトンに溶解した ものを $\mathrm{GC} / \mathrm{MS}$ 用の試験溶液とした。

$\mathrm{AK}$ 標準品を上記に従って処理し， GC/MS 分析した 際のマスクロマトグラムを Fig. 1 に示した. Fig. 2 に示 したような SA と類似の $N$-メチル化体とO-メチル化体 と思われる 2 つのピークが保持時間 8.7 分, 14.0 分に認 められた。なお，GC のカラムの特性から，より極性の高 い $N$-メチル化体の方が先に検出されるものと考えられ るため, 保持時間 8.7 分のピークが $N$-メチル-AK, 保持 時間 14.0 分のピークが $O-x$ チル $\mathrm{AK}$ と考えられる.こ の各々のピークについて質量スペクトルを測定したもの をFig. 3 に示した. $N$-メチル-AK では, $m / z 177$ の分子 イオンピーク及びフラグメントイオンとして,$m / z 28$, 43, 56, 69 及び 85 が, $O-x$ チル $\mathrm{AK}$ では $m / z 177$ の分 子イオンピーク及びフラグメントイオンとして,$m / z$ $28,43,55,70,83$ 及び 162 が検出された.

次に HPLC でAK を検出したトロピカル，オレンジ， アップルの 3 種の清凉飲料水とインスタントココアの マスクロマトグラムを Fig. 4 に示したが，いずれの試料 からも $\mathrm{AK}$ 標準品同様, 保持時間 8.7 分及び 14.0 分付 


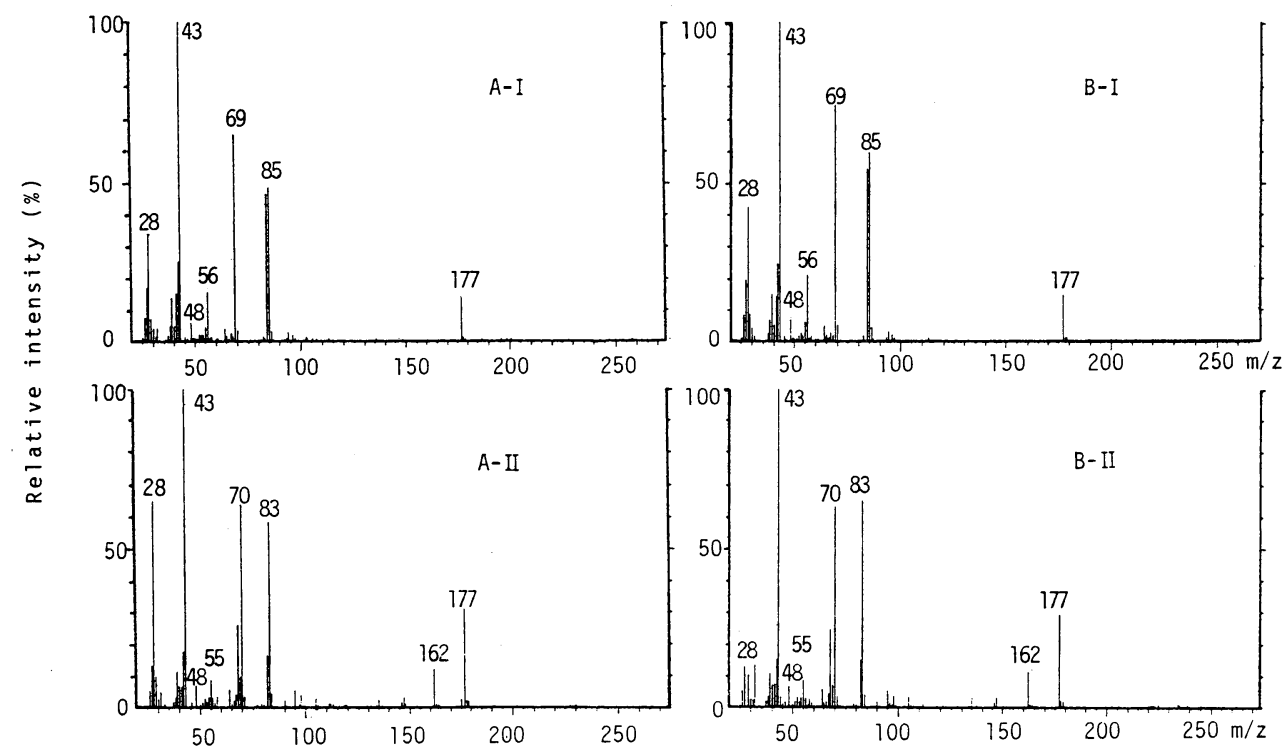

Fig. 5. Mass spectra of methylated derivatives of $\mathrm{AK}$ extracted from samples

A-I: tropical juice ( $N$-methyl-AK); A-II: tropical juice ( $O$-methyl-AK); B-I: instant cocoa $(N$-methyl-AK); B-II: instant cocoa ( $O$-methyl-AK)

近にピークが認められた。 また，この各々のピークにつ いて質量スペクトルを測定し，その一例を Fig. 5 に示し たが，いずれの試料のピークについても $\mathrm{AK}$ 標準品と同 様の分子イオンピーク及びフラグメントイオンが得ら れ， $\mathrm{AK}$ の確認ができた．以上の結果から，本法により AK についての確認が可能であるものと考えられる.

\section{まとめ}

前報1に従って, 輸入, 国産及び海外渡航時に購入した 食品 203 検体について AK, SA 及び APM の甘味料の 検查を行い，その使用状況について調査を行った。

清涼飲料水及び粉末清凉飲料でアメリカ産の 3 検体 から $\mathrm{SA}$ と $\mathrm{APM}$ を，イギリス産の 4 検体から $\mathrm{AK}$ と APM を, 国産品の 4 検体から SA を, 1 検体から SA と APM を検出した. なお，これらの製品はいわゆる「ダイ エット食品」である表示があった。なお，輸入品は甘味 料が併用して使用され，国産品は単独で使用される傾向 が認められた，また，固形食品のうち，国産品の漬物類 3 検体，菓子類 1 検体から SA が検出された.

$\mathrm{AK}$ の確認について GC/MS による方法を検討したと ころ, 試料を透析し, 酶酸エチル抽出した後ジアゾメ夕 ンーエーテル溶液によりメチル化を行い，その誘導体を GC/MS 分析する方法により AK の確認ができた.
文献

1) 守安貴子, 斎藤和夫, 中里光男, 石川ふさ子, 藤沼賢司, 二島太一郎：衛生化学 37, 97 102 (1991).

2) 日本薬学会編：“衛生試験法・注解 1990” p. 493 495 (1990), 金原出版.

3) 井部明広, 斎藤和夫, 中里光男, 菊地洋子, 藤沼賢司, 直 井家壽太, 二島太一郎：食衛誌. 26, 1 6 (1985).

4) Rymon, L. G.-W. von, Brixius, H-Ch.: Z. Lebensm. Unters. Forsch. 168, 212 213 (1979).

5) Zache, U, Grunding, H.: ibid. 184, 503 509 (1987).

6) Veerabhadrarao, M., Narayan, M.S., Kapur, O.: J. Assoc. Off. Anal. Chem. 70, 578 582 (1987).

7) Lawrence, J. F.: Analyst 112, 879 881 (1987).

8) Großpietsch, H., Hachenberg, H.: Z. Lebensm. Unters. Forsch. 171, 41 43 (1980).

9）守安貴子, 斎藤和夫, 中里光男, 菊地洋子, 藤沼賢司, 二 島太一郎：食衛誌. 30, 164 169 (1989).

10) Atle Hannisdal: Z. Lebensm. Unters. Forsch. 194, 517 〜19 (1992).

11）日本化学会編：実験化学講座，20, 373 (1963).

12) 厚生省生活衛生局食品保健課検疫所業務管理室輸出入検 查係：食品衛生研究 42, 81 108 (1992).

13）食品化学新聞社編：“別冊フードケミカル 4 甘味料総覧” p. $244 \sim 250$ (1990).

14）食品化学新聞社編：食品添加物総覧，p. 41４3 (1992) 